\title{
Thermal analysis of a parabolic trough solar collector with synthetic oil as working fluid using a computational tool
}

\section{Análisis térmico de un concentrador solar de canal parabólico con aceite sintético como fluido de trabajo utilizando una herramienta computacional}

ENCISO, Contreras Ernesto $\dagger^{*}$, DE LA CRUZ, Alejo Jesús, ALCOCER, Guillermo Irving Cardel and BARBOSA, Saldaña Juan Gabriel

\section{Tecnológico de Estudios Superiores de Ecatepec}

Instituto Politécnico Nacional

ID $1^{\text {st }}$ Author: Contreras Ernesto, Enciso / ORC ID: 0000-0003-4388-331X, CVU CONACYT ID: 333418

ID $1^{\text {st }}$ Coauthor: Alejo Jesús, De La Cruz / ORC ID: 0000-0001-5072-3985, CVU CONACYT ID: 173289

ID $2^{\text {nd }}$ Coauthor: Guillermo Irving Cardel, Alcocer / ORC ID: 0000-0002-3008-8072

ID $3^{\text {rd }}$ Coauthor: Saldaña Juan Gabriel, Barbosa / ORC ID: 0000-0001-8590-8082, CVU CONACYT ID: 84440

DOI: $10.35429 / J T P .2020 .17 .6 .1 .9$

Received January 15, 2020; Accepted April 01, 2020

\begin{abstract}
This work describes the use of a computational tool to assess a previously built parabolic trough solar collector (PTC) that uses a working fluid in liquid state. This work is focused on the thermal analysis of a PTC collector considering two common used synthetic oils: Syltherm 800 and Therminol VP1. The designing characteristics of the commercial LS3 solar collector was selected and as solar resource, the solar irradiance that reaches Mexico City was used with twelve monthly average values along the year. The computational tool provides thermal and flow data for every synthetic oil and for every solar irradiance value used. The most important data computed is the mass flow, which is obtained through iterative processes until the necessary value is found, in order to satisfy the working fluid final temperature for the synthetic oil, once the optimum mass flow value is found, the collector thermal parameters are computed, such as: heat gain, heat losses, thermal efficiency, and the temperatures for the absorber and coating tubes. The computational tool can assess any PTC collector with any working fluid in liquid state, and the data obtained can be used to improve of modify the design of the collector for a better performance.
\end{abstract}

PTC collector, thermal analysis, synthetic oil

\section{Resumen}

Este trabajo describe una herramienta computacional para evaluar el desempeño de un concentrador solar de canal parabólico (PTC) previamente construido que usa un fluido de trabajo en estado líquido. Este trabajo se enfoca en el análisis térmico del concentrador, considerando dos aceites térmicos comúnmente usados: Syltherm 800 y Therminol VP1. Se utilizaron los datos del concentrador comercial LS3 y como fuente de energía, se utilizó la irradiancia solar de la Ciudad de México con doce valores promedio. La herramienta computacional proporciona parámetros térmicos y de flujo para cada aceite térmico y para cada valor de irradiancia solar. El dato más importante que se calcula es el flujo másico, el cual se obtiene a través de procesos iterativos hasta que se encuentra el valor necesario para satisfacer la condición de temperatura final del aceite térmico, una vez que el valor óptimo es encontrado, se calculan los datos térmicos del concentrador, éstos son: flujo de calor útil, flujo de calor perdido, eficiencia térmica y las temperaturas para los tubos absorbedor y transparente. La herramienta computacional puede evaluar cualquier concentrador PTC para cualquier fluido de trabajo en estado líquido y los datos obtenidos pueden servir para mejorar o modificar el diseño del concentrador mejorando su desempeño.

Concentrador PTC, análisis térmico, aceite térmico

Citation: ENCISO, Contreras Ernesto, DE LA CRUZ, Alejo Jesús, ALCOCER, Guillermo Irving Cardel and BARBOSA, Saldaña Juan Gabriel. Thermal analysis of a parabolic trough solar collector with synthetic oil as working fluid using a computational tool. Journal of Technological Prototypes. 2020. 6-17: 1-9.

\footnotetext{
* Correspondence to Author (email: eencisoc@hotmail.com)

$\dagger$ Researcher contributing first author
} 


\section{Introduction}

The overexploitation of conventional sources of energy is one of the most serious problems that is affecting the entire world in many aspects, as a result of this activity, the prices of the fossil fuels are increasing every day what is causing the shortage in some places where the fuel must be bought from other countries. Also, the use of fossil fuels is the most dangerous source of air pollution causing the diminishing quality of the air, affecting the human health and in general the entire life of the world. Other problem that the mankind is facing, because of the use of fossil fuels is the global warming, this effect is causing the raising of the global world temperature and as a consequence, the climate is changing augmenting the strength of natural phenomena such as hurricanes, droughts, flooding, heatstrokes, etc.

To solve or diminish the problems before mentioned, an alternative is the use of renewable energies to supply or substitute the conventional sources of energy. The use of renewable energies has been increasing for the last twenty years, some reasons are the decrease of the technology price, the information diffusion about the advantages of it use and the emergent technologies that reduce que price or the size of the total installation.

Among the renewable energies investigated, the solar energy has the most potential for using in different ways, such as: energy generation, heat processes for the industry or to heat water for houses, hotels, hospitals, etc. Only in two days, the planet receives the energy equivalent to all the fossil fuels reserves known until now, this is equivalent to 60 times the annual consumption of the human society, this data provides an ideal of the solar energy potential to satisfy the energy human necessities (Arancibia, 2010).

Among the devices built to take advantage of the solar energy for being transformed into thermal energy, the parabolic trough collectors (PTC) are the most mature, developed and advanced solar technology to reach medium temperatures $\left(60-400{ }^{\circ} \mathrm{C}\right)$.
The larger application for electric generation using PTC collectors with synthetic oil as heat transfer fluid is the solar power plant SEGS located in southern California, E.E.U.U., with a total installed capacity of $354 \mathrm{MW}$, divided into eight zones, SEGS I with a capacity of 14MW. SEGS II-VI with a capacity of 30MW each one and SEGS VIII-IX with 80 MW each one (Kalogirou, 2009).

The majority of PTC collectors or power plants use synthetic oil as heat transfer fluid, although different working fluids have been analysed. The commercial Eurotrough ET-150 PTC collector was investigated energetically and exergetically for a great temperature range from $300 \mathrm{~K}$ to $1300 \mathrm{~K}$ using different heat transfer fluids, pressurized water, Therminol VP-1, nitrate molten salt, sodium liquid, air, carbon dioxide and helium, the study was realized using a the EES tool where the maximum efficiency is varying depending on the inlet temperature and mass flow (Bellos et al, 2017).

Even the direct steam generation system has been under study for the last years, the need to remove the heat exchanger is one of the advantages, nevertheless this kind of steam generation presents some problems, the flow must show some specific flow patterns to avoid larges temperature gradients in the absorber tube, these gradients cause the excessive deflection for the tube and if a coating tube is used to surround the absorber tube, this could be damaged or broken, also an absorber tube with higher thermal conductivity is recommended (Almanza, 1997, Rojas, 2008).

In order to reduce the electricity cost and improve the overall efficiency, some studies have been developed to predict the thermal behavior of PTC collectors, such as a numerical model based on Finite Volume Method where hot water and steam generation are used as heat transfer fluids (Hachicha, 2016), also a numerical study was carried out to analyze the dependent on the heat loss from the absorber tube at its operation temperature to predict the useful heat gain, selecting evacuated and non-evacuated glass tubes employed as a control radiative and convective heat losses (Premjit, et al, 2011). 
The heat transfer fluid enhancement in a PTC collector become essential to transfer the maximum amount of heat, which can reduce the total system size, some studies are focused on the feasibility of heat transfer augmentation techniques for PTC absorber tubes. These includes the use of nanofluids with or without inserts and use of inserts with base fluids, also the study was applied depending on the kind of flow, laminar or turbulent, the use of inserts with base fluid is beneficial in laminar region while nanofluids with insert is justified for turbulent regime (Sandeep and Arunachala, 2017).

The computational tools have become an important role in the knowledge generation and technology development, the design and simulation of processes and devices could be made changing the variables involved without the necessity to build a prototype, this advantage becomes the processes cheaper and flexible.

In this work, a developed computational tool is used to realize the thermal analysis of a parabolic trough solar collector that uses synthetic oil as heat transfer fluid, the data used for this purpose were obtained from the LS3 (Luz Solar third generation) PTC collector constructed in Sandia National laboratories, E.E.U.U. and used for electric generation. The next sections of this work presents the methodology used to obtain the flow and thermal data using the designing parameters and construction materials of the PTC collector selected in order to assess its overall performance.

\section{Methodology}

In this work, the characteristics and designing of the commercial LS3 solar collector are used to realize the flow and thermal analysis. The LS3 solar collector was developed by the American-Israeli company Luz Industries Ltd. and currently is applied in the Solar Electric Generation Systems located at the southern of California, E.E.U.U., this collector was based on a broad space frame structure, which is more resistant to bending and torsion (Günther et al, 2011).
Currently the commercial solar collector plants based on PTC collectors principally used for electrical generation uses synthetic thermal oil as working heat transfer fluid (HTF) because of its thermal characteristics. The HTF has the task to accumulate the thermal energy in the collectors absorber tube and to transport it to the power block, after that, the energy gained by the synthetic oil is transferred to the water using a heat exchanger, once the temperature water is increasing, the evaporation process begins to reach the steam necessary to supply the turbine, this energy transferred by the synthetic oil is the energy used to develop the Rankine cycle for the mechanical power production and consequently the electrical energy generation.

The use of synthetic oil as HTF has some advantages and currently is the configuration most used to produce thermal energy. The synthetic oil contains relative lower heat capacity; this characteristic is convenient because the fluid needs only less quantity of energy to increase the temperature, also presents more advantages such as: high evaporation temperature; the regular temperature for the synthetic oil in a PTC collector for electrical generation is around $400{ }^{\circ} \mathrm{C}$, low freezing temperature this is important because the majority of the solar fields have no freezing protection, thermal stability, low viscosity to reduce the frictional losses into the absorber tube, low cost investment and the availability.

For the purpose of this work, two heat transfer fluids are being analyzed, Syltherm 800 and Therminol VP1, which has been used for many applications in commercial PTC collectors power plants.

\section{Absorber tube thermal analysis}

The computational tool developed for PTC designing and assessment to realize the thermal analysis considers some assumptions. The HTF is considered always in liquid state and the mathematical models used to predict the main variables are considered as average values. 
The solar energy available to be transferred into the absorber tube depends on the area of aperture, the solar irradiance must be provided or estimated using measured values or computed using a mathematical model, other important parameters involved into the analysis are the thermal characteristics of the HTF as well as the optical parameters of the parabola material, the absorber tube selective surface and the absorber and coating tubes materials.

The absorber tube is considered to be surrounded by a concentric coating transparent tube to minimize the convection heat losses and only one coating tube is considered.

The process begins with the computation of heat gained by the HTF, as shows the equation (1).

$\mathrm{Q}_{\mathrm{u}}=\dot{\mathrm{m}} \mathrm{C}_{\mathrm{p}}\left(\mathrm{T}_{\mathrm{fe}}-\mathrm{T}_{\mathrm{fi}}\right)$

Where, $\dot{m}$ represents the mass flow $(\mathrm{kg} / \mathrm{s})$ and is considered the most important parameter involved into the calculations for the entire process, $\mathrm{C}_{\mathrm{p}}$ is the heat capacity $(\mathrm{J} / \mathrm{kg})$, $\mathrm{T}_{\mathrm{fe}}$ and $\mathrm{T}_{\mathrm{fi}}$ are the outer HTF temperature at the end of the absorber tube and the inner HTF temperature at the beginning of the absorber tube respectively $\left({ }^{\circ} \mathrm{C}\right)$.

The heat transfer coefficient $\left(\mathrm{W} / \mathrm{m}^{2} \mathrm{~K}\right)$ for the working fluid depends on the Reynolds number (dimensionless) and two factors related with this value and can be computed using the equations (2) to (5).

$$
\begin{aligned}
& \mathrm{Re}=\frac{4 \dot{\mathrm{m}}}{\pi \mathrm{D}_{\mathrm{ri}} \mu_{\mathrm{l}}} \\
& \mathrm{Xi}=\frac{1}{(1.82 \log (\mathrm{Re})-1.64)^{2}} \\
& \lambda=1+\frac{900}{\mathrm{Re}} \\
& \mathrm{h}_{\mathrm{l}}=\left(\frac{\mathrm{k}_{\mathrm{l}}}{\mathrm{D}_{\mathrm{ri}}}\right)\left(\frac{0.125{\mathrm{Xi} \mathrm{Re} P \mathrm{Pr}_{1}}^{0.656}}{\lambda+4.5 \mathrm{Xi}^{0.5}\left(\mathrm{Pr}_{\mathrm{l}}^{0.666}-1\right)}\right)
\end{aligned}
$$

In the recent equations, $\mu_{1}$ represents the dynamic viscosity of the working fluid $(\mathrm{Pa} \cdot \mathrm{s})$, $\mathrm{Pr}_{\mathrm{l}}$ is the Prandtl number (dimensionless), $\mathrm{k}_{\mathrm{l}}$ is the thermal conductivity $(\mathrm{W} / \mathrm{mK})$ and $\mathrm{D}_{\mathrm{ri}}$ is the absorber tube internal diameter $(\mathrm{m})$.
All the variables must be computed simultaneously as the mass flow is varying in order to compute the outer temperature of the absorber tube as well as the temperatures of the coating tube.

The outer and inner surfaces of the absorber tube are unknown and must be computed, this can be realized using the Newton's cooling law and the Fourier's law, this is possible with the assumption that the heat flow across the absorber tube is conserved.

$\mathrm{Q}_{\mathrm{u}}=\frac{\mathrm{T}_{\mathrm{ri}}-\mathrm{T}_{\mathrm{l}-\mathrm{av}}}{\pi \mathrm{L} \mathrm{D}_{\mathrm{ri}} \mathrm{h}_{\mathrm{l}}}$

$\mathrm{Q}_{\mathrm{u}}=\frac{2 \pi \mathrm{Lk}_{\mathrm{r}}\left(\mathrm{T}_{\mathrm{re}}-\mathrm{T}_{\mathrm{ri}}\right)}{\ln \left(\frac{\mathrm{D}_{\mathrm{re}}}{\mathrm{D}_{\mathrm{ri}}}\right)}$

Where, $\mathrm{T}_{\mathrm{ri}}$ and $\mathrm{T}_{\mathrm{re}}$ are the inner and outer absorber tube temperatures $\left({ }^{\circ} \mathrm{C}\right), \mathrm{T}_{\mathrm{l}-\mathrm{av}}$ is the working fluid average temperature $\left({ }^{\circ} \mathrm{C}\right)$, $\mathrm{L}$ is the total length of the absorber tube $(\mathrm{m}), \mathrm{D}_{\mathrm{re}}$ is the outer absorber tube diameter and $\mathrm{k}_{\mathrm{r}}$ represents the thermal conductivity of the absorber tube $(\mathrm{W} / \mathrm{mK})$.

The mathematical model also considers the thermal losses. The inner temperature of the HTF is imposed by the user and depending of the average fluid temperature the computational tool obtains the thermal characteristics of the synthetic oil. The heat losses begin at the outer surface of the absorber tube passing through the coating tube to the air of the ambient, the figure (1) represents a diagram of the heat losses.

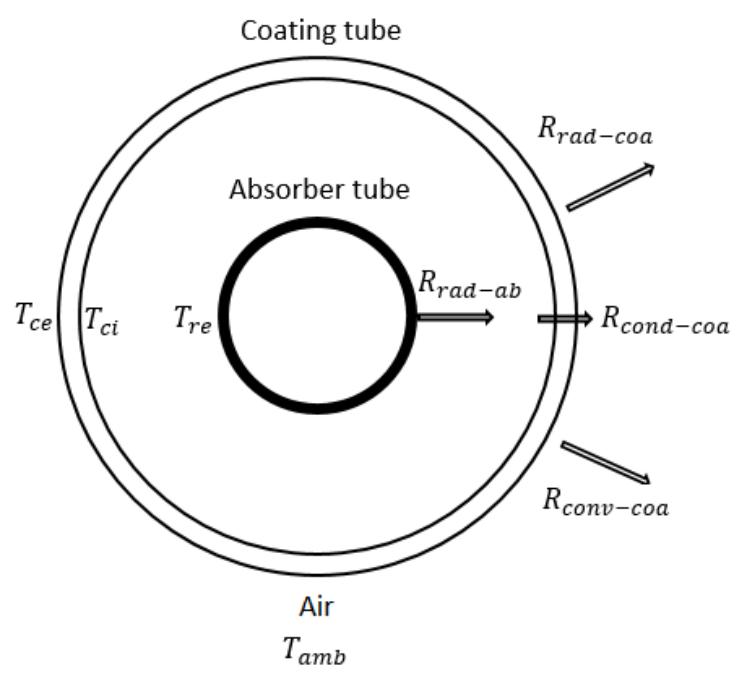

Figure 1 Thermal losses from the absorber and coating tubes of a PTC collector 
Considering the conservation of the heat lost from the absorber tube surface to the inner surface of the coating tube, regarding only the thermal losses for radiation, thermal losses for convection are not considered because of the assumption that the space between both tubes is evacuated, after that the heat passing through the coating tube as heat conduction and finally, from the outer surface of the coating tube to the ambient air, two effects are considered, the thermal radiation and convection, the next equations governs the heat lose analysis (Duffie and Beckman, 2013).

$$
\begin{aligned}
& \mathrm{Q}_{\mathrm{l}}=\frac{\pi \mathrm{D}_{\mathrm{re}} \mathrm{L} \sigma\left(\mathrm{T}_{\mathrm{re}}^{4}-\mathrm{T}_{\mathrm{ci}}^{4}\right)}{\frac{1}{\varepsilon_{\mathrm{r}}}+\frac{1-\varepsilon_{\mathrm{c}}}{\varepsilon_{\mathrm{c}}}\left(\frac{\mathrm{D}_{\mathrm{re}}}{\mathrm{D}_{\mathrm{ci}}}\right)} \\
& \mathrm{Q}_{\mathrm{l}}=\frac{2 \pi \mathrm{k}_{\mathrm{c}} \mathrm{L}\left(\mathrm{T}_{\mathrm{ci}}-\mathrm{T}_{\mathrm{co}}\right)}{\ln \left(\frac{\mathrm{D}_{\mathrm{co}}}{\mathrm{D}_{\mathrm{ci}}}\right)} \\
& \mathrm{Q}_{\mathrm{l}}=\pi \mathrm{D}_{\mathrm{co}} \mathrm{Lh}_{\mathrm{a}}\left(\mathrm{T}_{\mathrm{co}}-\mathrm{T}_{\mathrm{a}}\right)+\varepsilon_{\mathrm{c}} \pi \mathrm{D}_{\mathrm{co}} \mathrm{L} \sigma\left(\mathrm{T}_{\mathrm{co}}^{4}-\mathrm{T}_{\mathrm{a}}^{4}\right)
\end{aligned}
$$

In the previous equations, $\mathrm{T}_{\mathrm{ci}}$ and $\mathrm{T}_{\mathrm{co}}$ are the inner and outer temperatures of the coating tube $\left({ }^{\circ} \mathrm{C}\right), \mathrm{T}_{\mathrm{a}}$ is the ambient air temperature $\left({ }^{\circ} \mathrm{C}\right), \mathrm{D}_{\mathrm{ci}}$ and $\mathrm{D}_{\mathrm{co}}$ are the inner and outer coating tube diameters $(\mathrm{m}), \sigma$ is the Stefan-Boltzmann constant $\left(W / m^{2} K^{4}\right), \mathrm{k}_{\mathrm{c}}$ is the coating tube thermal conductivity $(\mathrm{W} / \mathrm{mK})$, $\varepsilon_{\mathrm{c}}$ and $\varepsilon_{\mathrm{r}}$ represents the emissivities of the coating and absorber tube respectively, and finally, $h_{a}$ is the heat transfer coefficient of the ambient air $\left(\mathrm{W} / \mathrm{m}^{2} \mathrm{~K}\right)$.

The equation (8) only considers the radiation losses because of the assumption that the space between the absorber and coating tube is evacuated, the equation (9) represents the conduction heat passing through the coating tube and the equation (10) considers the effects of convection and radiation from the coating tube to the ambient air.

Finally, to complete the thermal analysis, the heat transfer coefficient of the ambient air must be computed, this is possible using the velocity of the air and for the mathematical model, forced convection across the external surface of a cylinder is considered. The Nusselt number of the air in function of the Reynolds number is computed as follows.

$\mathrm{Re}_{\mathrm{a}}=\frac{\mathrm{VD}_{\mathrm{ce}}}{\mathrm{v}_{\mathrm{a}}}$
For $\operatorname{Re}_{\mathrm{a}}>0.1$ to $\mathrm{Re}_{\mathrm{a}} \leq 1000$

$\mathrm{Nu}=0.4+0.54 \mathrm{Re}_{\mathrm{a}}$

and for $\operatorname{Re}_{\mathrm{a}}>1000$

$\mathrm{Nu}=0.3 \mathrm{Re}_{\mathrm{a}}$

$\mathrm{h}_{\mathrm{a}}=\frac{\mathrm{Nu} \mathrm{k} \mathrm{a}}{\mathrm{D}_{\mathrm{ce}}}$

Where, $\mathrm{V}$ is the air velocity $(\mathrm{m} / \mathrm{s}), \mathrm{Nu}$ is the air Nusselt number (dimensionless) and $\mathrm{k}_{\mathrm{a}}$ is the air thermal conductivity $(\mathrm{W} / \mathrm{mK})$.

The process before mentioned is followed for the computational tool to realize the absorber tube thermal analysis, the next section presents the results using the designing of a real PTC solar collector using thermal oil as working fluid.

\section{Results}

The thermal analysis of the absorber tube in a PTC collector using this computational tool needs some initial parameters that the user can introduce to the interface freely. These parameters according to the construction

\begin{tabular}{|c|c|}
\hline \multicolumn{2}{|l|}{ Parabola dimensions } \\
\hline Aperture (m) & 5.7 \\
\hline Length $(\mathrm{m})$ & 12 \\
\hline Rim angle $\left({ }^{\circ}\right)$ & 80 \\
\hline Intercept factor & 0.93 \\
\hline \multicolumn{2}{|c|}{ Construction materials characteristics } \\
\hline Reflectivity of the parabola surface & 0.94 \\
\hline \multicolumn{2}{|l|}{ Selective surface } \\
\hline Absorptivity & 0.96 \\
\hline Emissivity & 0.15 \\
\hline \multicolumn{2}{|l|}{ Absorber tube } \\
\hline Internal diameter $(\mathrm{m})$ & 0.059 \\
\hline External diameter $(\mathrm{m})$ & 0.07 \\
\hline Thermal conductivity (W/mK) & 15 \\
\hline \multicolumn{2}{|l|}{ Coating tube (Pyrex) } \\
\hline Internal diameter $(\mathrm{m})$ & 0.101 \\
\hline External diameter $(\mathrm{m})$ & 0.115 \\
\hline Thermal conductivity (W/Mk) & 1.2 \\
\hline Transmisivity & 0.96 \\
\hline Emissivity & 0.9 \\
\hline
\end{tabular}
materials of the commercial LS3 PTC collector are shown in the table (2).

Table 1 Construction characteristics of the LS3 solar collector.

Source: (Fernández-García et al, 2010) 
The energy source (solar irradiance), depends on the place where the PTC is pretended to be installed, the solar irradiance is intermittent and for the assessment of a PTC collector, a monthly average value must be used. Mexico City is the place selected for this analysis, due to the great available solar energy along the year.

The computational tool can analyse the thermal characteristics of the PTC collector considering the twelve values of average monthly solar irradiance. The table (2) shows the twelve values considered for this work.

\begin{tabular}{|l|r|}
\hline \multicolumn{2}{|l|}{$\begin{array}{l}\text { Solar irradiance average for every month in Mexico } \\
\text { City }\left(\boldsymbol{W} / \mathbf{m}^{\mathbf{2}}\right) \text {. }\end{array}$} \\
\hline January & 474.01 \\
\hline February & 530.24 \\
\hline March & 543.79 \\
\hline April & 548.79 \\
\hline May & 502.65 \\
\hline June & 507.17 \\
\hline July & 436.16 \\
\hline August & 460.04 \\
\hline September & 406.76 \\
\hline October & 467.58 \\
\hline November & 497.40 \\
\hline December & 442.47 \\
\hline
\end{tabular}

Table 2 Solar irradiance monthly average values for Mexico City

Source: (Enciso et al, 2018)

Other important variable is the solar irradiation incidence angle, due to the length of the PTC collectors, if a solar tracking system is considered to be implemented, only one axis solar tracking system can be installed, the most used and for this reason, the same considered for this analysis is the North-South oriented and East-West displacement.

The computational tool also can compute an average solar incidence angle along the year and depends on the latitude from the place where the PTC collector is going to be installed, for Mexico City and the solar tracking system considered, the incidence angle is $\theta=$ $17.47^{\circ}$.

Finally, ambient data and properties for the working fluids are needed.
The properties for the working fluid are obtained from the average fluid temperature, the temperatures at the beginning and at the end of the PTC collector can be introduced freely by the user, the LS3 collector was designed to operate at a maximum temperature of $390^{\circ} \mathrm{C}$ for electric generation, this temperature value is considered for this thermal analysis and an initial temperature of $30^{\circ} \mathrm{C}$, the table (3) shows the data used in this analysis.

\begin{tabular}{|c|c|}
\hline \multicolumn{2}{|c|}{ Average ambient data for Mexico City } \\
\hline Temperature $\left({ }^{\circ} \mathrm{C}\right)$ & 22 \\
\hline Air velocity $(\mathrm{m} / \mathrm{s})$ & 1.9 \\
\hline \multicolumn{2}{|l|}{ Working fluid properties } \\
\hline \multicolumn{2}{|l|}{ Syltherm 800} \\
\hline Heat capacity $(\mathrm{J} / \mathrm{kgK})$ & 1933 \\
\hline Thermal conductivity $(\mathrm{W} / \mathrm{mK})$ & 0.0993 \\
\hline Prandtl number & 18.688 \\
\hline Dynamic viscosity $(\mathrm{Pa} \cdot \mathrm{s})$ & $0.96 \times 10^{-3}$ \\
\hline Density $\left(\mathrm{kg} / \mathrm{m}^{3}\right)$ & 763.78 \\
\hline \multicolumn{2}{|l|}{ Therminol VP-1 } \\
\hline Heat capacity $(\mathrm{J} / \mathrm{kg})$ & 2075 \\
\hline Thermal conductivity $(\mathrm{W} / \mathrm{mK})$ & 0.112 \\
\hline Prandtl number & 6.819 \\
\hline Dynamic viscosity $(\mathrm{Pa} \cdot \mathrm{s})$ & $0.368 \times 10^{-3}$ \\
\hline Density $\left(\mathrm{kg} / \mathrm{m}^{3}\right)$ & 904 \\
\hline
\end{tabular}

Table 3 Thermal properties for the working fluids. Source: (Enciso,

2012) https://es.weatherspark.com/y/5674/Clima-promedio-enCiudad-de-M\%C3\%A9xico-M\%C3\%A9xico-durantetodo-el-a\%C3\%B1o

All the variables before explained and mentioned must be introduced to the software interface, the computational tool shows in separate section, the properties that must be introduced for every part of the PTC collector. The figure (2) shows the software interface for PTC collector assessment. This software is validated and can be consulted in Enciso, 2012.

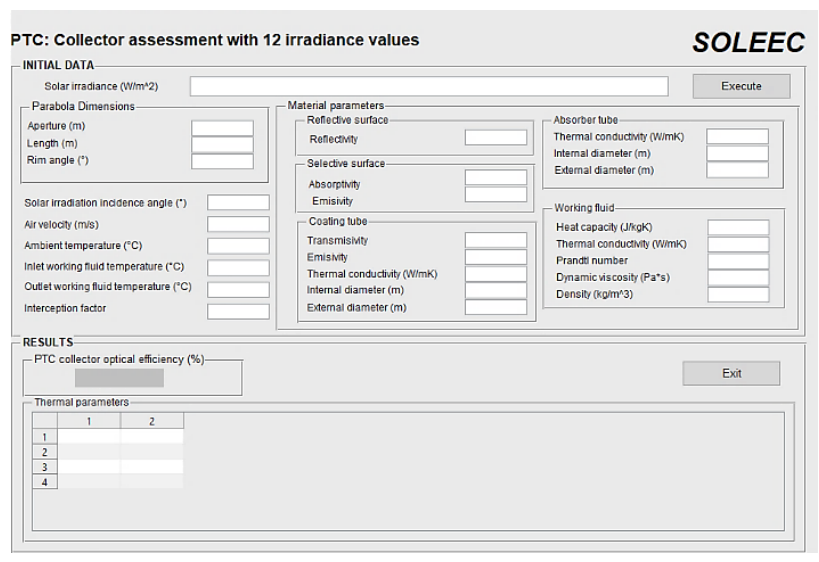

Figure 2 Interface of the computational tool to realize an assessment of a PTC collector with 12 average values of solar irradiance 
Once the software interface is executed, the results for the thermal analysis for every solar irradiance value is showed in form of table for the better comprehension. The tables (4) and (5) show the results for both synthetic oils analyzed in this work.

\begin{tabular}{|c|c|c|c|c|c|c|}
\hline Month & $\begin{array}{l}\text { Heat } \\
\text { gain } \\
\text { (W) }\end{array}$ & $\begin{array}{l}\text { Heat } \\
\text { losses } \\
\text { (W) }\end{array}$ & $\begin{array}{l}\text { Mass } \\
\text { flow } \\
\left(\mathrm{kg} / \mathrm{m}^{3}\right)\end{array}$ & $\begin{array}{l}\text { Efficiency } \\
(\%)\end{array}$ & $\begin{array}{l}\text { Outer } \\
\text { surface } \\
\text { absorber } \\
\text { tube }\left({ }^{\circ} \mathrm{C}\right)\end{array}$ & $\begin{array}{l}\text { Inner } \\
\text { Surface } \\
\text { coating tube } \\
\left({ }^{\circ} \mathrm{C}\right)\end{array}$ \\
\hline January & 1391.8 & 15822 & 0.0021 & 4.29 & 660.86 & 193.73 \\
\hline February & 1670.1 & 17042 & 0.0025 & 4.60 & 678.62 & 204.49 \\
\hline March & 1809.3 & 17540 & 0.0027 & 4.86 & 685.66 & 209.29 \\
\hline April & 1809.3 & 17540 & 0.0027 & 4.82 & 685.66 & 209.29 \\
\hline May & 1530.9 & 16471 & 0.0023 & 4.45 & 670.45 & 199.70 \\
\hline June & 1600.5 & 16767 & 0.0024 & 4.61 & 674.69 & 202.09 \\
\hline July & 1252.6 & 15062 & 0.0019 & 4.20 & 649.40 & 187.78 \\
\hline August & 1391.8 & 15822 & 0.0021 & 4.42 & 660.86 & 193.73 \\
\hline September & 1183.0 & 14646 & 0.0018 & 4.25 & 642.79 & 183.03 \\
\hline Octuber & 1391.8 & 15822 & 0.0021 & 4.35 & $\begin{array}{ll}660.86 \\
\end{array}$ & 193.73 \\
\hline November & 1530.9 & 16471 & 0.0023 & 4.50 & 670.45 & 199.70 \\
\hline December & 1252.6 & 15062 & 0.0019 & 4.14 & 649.40 & 187.78 \\
\hline
\end{tabular}

Table 4 Evaluation of the PTC collector using Syltherm 800 synthetic oil as heat transfer fluid.

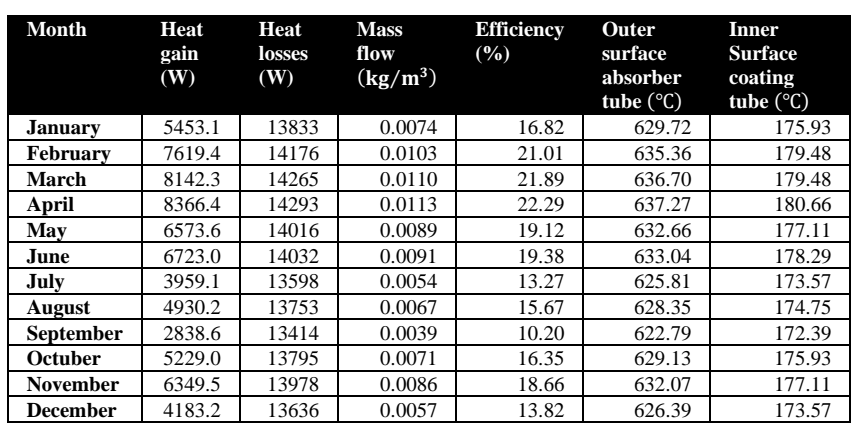

Table 5 Evaluation of the PTC collector using Therminol VP-1 synthetic oil as heat transfer fluid.

The mass flow is the most important parameter in the results, this is directly related to the computation of the other thermal parameters, the computational tool takes an initial mass flow value and develops an iterative process to predict the necessary mass flow in order to reach the temperature of the working fluid dictated by the user, that means, the mass flow represents the necessary time that the working fluid must be exposed to the solar irradiance to reach the temperature condition. As can be seen in table (5), due to the characteristics of every synthetic oil, the mass flow for Therminol VP1 is higher in average $70.36 \%$ than Syltherm 800 for reaching the $390^{\circ} \mathrm{C}$ desired, so the residential time for the working fluid is less, this characteristic is beneficial and can be observed in the other thermal characteristics.
The first parameter directly influenced by the mass flow is the heat gain, this represents the quantity of useful energy for the collector from all the energy that reaches the entire collector, the higher the mass flow, the higher the heat gained by the collector, that means that using Therminol VP1, the working fluid transfer more energy to the storage tank, and at the end of a period of time, more energy is collected. The month which the collector take more advantage of the solar energy is april with 8366.4 W against september with the less energy collected with $2838.6 \mathrm{~W}$ this represents $66.07 \%$ less energy. Comparing the month with the major quantity of heat gain for both synthetic oils, for Syltherm 800 the heat gain in april is $1809.3 \mathrm{~W}$, this is $78.37 \%$ less useful energy in comparison with Therminol VP1, even in the month with less solar irradiance (september) using Therminol VP1 collects more useful energy. The importance of analyzing every month is to design the minimal size of the PTC collector in order to satisfy the quantity of energy necessary to cover the useful energy needed of the process for all the year.

The heat losses also play an important role in the thermal analysis, the thermal radiation is the most significant mechanism of lost thermal energy, so when the absorber tube external temperature increases, the thermal radiation losses also increase. The absorber tube temperature in both cases is relatively high having an average along the year of $665.81^{\circ} \mathrm{C}$ for Syltherm 800 and $630.7^{\circ} \mathrm{C}$ for Therminol VP1, this represents the increase of the thermal losses for both cases affecting directly to the overall thermal efficiency.

The mass flow also is important for the thermal losses, when the mass flow increases, the absorber tube temperature decreases, as a consequence, the thermal losses also decreases. Considering the before mentioned and the heat gain, the overall thermal efficiency can be estimated for the PTC solar collector. As show the tables (5) and (6), the use of Therminol VP1 increases $73.29 \%$ the thermal efficiency against the efficiency when Syltherm 800 is used, so if the total energy collected in a period of time is considered, the use of Therminol VP1 is recommended. 
Using the computational tool, the user can assess a PTC collector with any working fluid that is remaining in a single phase state, the user can introduce freely the characteristics of every PTC collector section and the properties of the working fluid. The advantage of using a computational tool is the capacity to evaluate an existing PTC collector and the results can be used as starting point for the collector's improvement and, if necessary, to consider the collector's redesign.

\section{Conclusions}

This work describes the use of a computational tool for PTC collector assessment. The analysis considers the designing characteristics of the commercial solar collector LS3 with two synthetic oils, Syltherm 800 and Therminol VP1 as working fluids remaining in liquid state during the process. Mexico City is the place where the PTC collector is pretended to be installed so the solar irradiance for this place is used as energy source.

An interface was designed, divided in sections where the user must provide the characteristics of the parabola, tubes materials, ambient data, the characteristics of the fluid and the solar irradiance. The results, in form of charts, show the thermal and flow characteristics of the PTC collector for every working fluid and for every average monthly solar irradiance values along the year.

The solar irradiance is intermittent and is necessary an average to use a single value for each month. April is the month for Mexico City with the maximum solar radiation quantity while september provides the less available energy, this is important because the designer can determine the PTC installation size in order to guarantee the temperature condition of the working fluid.

The thermal properties of every working fluid play an important role and the most important parameter computed is the mass flow, this variable is directly involved in the other thermal characteristics. The results show that the mass flow for Therminol VP1 is higher than for Syltherm 800 for $70.36 \%$ average for every month, this is beneficial because, if the mass flow increases, the heat gained by the collector also increases and diminishes the thermal losses.
The absorber tube temperature is the most important parameter for thermal losses, for both cases this value is relatively high with an average of $665.81^{\circ} \mathrm{C}$ for Syltherm 800 and $630.7^{\circ} \mathrm{C}$ for Therminol VP1. The radiation is the most significant heat transfer mechanism for thermal losses and a high absorber tube temperature represents a great thermal losses rate. The thermal efficiency increases $73.29 \%$ when Therminol VP1 is used compared with Syltherm 800.

This computational tool has the advantage of evaluating any PTC solar collector that uses any working fluid remaining in liquid state and the results can be used to modify or redesign the PTC collector in order to improve the performance.

\section{References}

Almanza, R., Lentz, A., and Jiménez, G. (1997). Receiver behavior in direct steam generation with parabolic troughs, Solar Energy, 61 (4), 275-278.

Arancibia, C., and Best-Brown, R. (2010). Energía del Sol, Ciencia, 61 (2), 10-17.

Bellos, E., Tzivanidis, C., and Antonopoulos, K., A. (2017). A detailed working fluid investigation for solar parabolic trough collectors, Applied Thermal Energy, 114, 374386.

Duffie, J., A., and Beckman, W,. A. (2013). Solar engineering of thermal processes, New Jersey, Estados Unidos, Wiley and Sons Inc.

Eck, M., Zarza, E., Einckoff, M., Rheinländer, J., and Valenzuela, L. (2003). Applied research concerning the direct steam generation in parabolic troughs, Solar Energy, 74, 341-351.

Enciso, C., E. (2012). Desarrollo de un software para el diseño de concentradores solares de canal parabólico. Tesis de Maestría. Instituto Politécnico Nacional. Ciudad de México, México. 
Enciso, C., E., Barbosa, S., J., G., Mora, O., A., Bonilla, B., W., C., Salazar, P., M., Aguilar, A., J., C., A., and Durán, M., P. (2018). Analysis and design of an integrated solar combined cycle power plant using the software SOLEEC, Journal of Renewable and Sustainable Enegy, $10,1-13$.

Fernández-García, A., Zarza, E., Valenzuela, L., and Pérez, M. (2010). Parabolic-trough solar collectors and their applications. Renewable and sustainable energy reviews, 14, 1695-1721.

Günther, M., Joemann, M., and Csambor, S. (2011). Advanced CSP teaching materials. Enermena.

Kalogirou, S., (2009). Solar Energy Engineering Processes and Systems, Elsevier.

Premjit, D., Yashavant, J., and Abhik, K., D. (2011). Numerical investigation of parabolic trough receiver performance with outer vacuum shell, Solar Energy, 85, 1910-1914.

Rojas. M., E., De Andrés, M., C., and González L. (2008). Designing capillary systems to enhace heat transfer in LS3 parabolic trough collectors for direct steam generation (DSG), Solar Energy, 82, 53-60

Sandeep, H., M., and Arunachala, U., C. (2017). Solar parabolic trough collectors: A review on heat transfer augmentation techniques, Renewable and Sustainable Energy Reviews, 69, 1218-1231. 